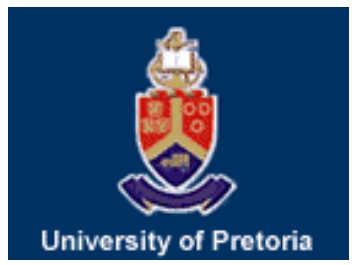

University of Pretoria

Department of Economics Working Paper Series

\author{
A Computable General Equilibrium Micro-Simulation Analysis of \\ the Impact of Trade Policies on Poverty in Zimbabwe \\ Margaret Chitiga \\ University of Pretoria \\ Ramos Mabugu \\ University of Pretoria \\ Tonia Kandiero \\ National Treasury \\ Working Paper: 2007-15 \\ September 2007
}

Department of Economics

University of Pretoria

0002, Pretoria

South Africa

Tel: +27 124202413

Fax: +27 123625207 


\title{
A Computable General Equilibrium Micro-Simulation Analysis of the Impact of Trade Policies on Poverty in Zimbabwe. ${ }^{1}$
}

\author{
Margaret Chitiga ${ }^{2}$ (University of Pretoria) \\ Ramos Mabugu ${ }^{3}$ (University of Pretoria) \\ Tonia Kandiero ${ }^{4}$ (National Treasury)
}

\begin{abstract}
1 This work was carried out with the aid of a grant from Poverty and Economic Policy (PEP) Research Network (www.pep-net.org), financed by the International Development Research Centre (IDRC). We are additionally grateful to the Laval University PEP team for intensive data and technical assistance. Special appreciation goes to Professors Bernard Decaluwe and John Cockburn, Dr Nabil Annabi ,Mr. Ismael Fofana and Professor Luc Savard. The paper has also benefited from comments by PEP workshop participants, especially Jim Davies. Comments from GTAP 2005 participants and the $10^{\text {th }}$ Annual African Econometric Society (AES) 2005 are also acknowledged. Suggestions from two anonymous referees are gratefully acknowledged. Any errors remain our own.
\end{abstract}

2 Corresponding author, Margaret Chitiga, University of Pretoria, Economics Department, Faculty of Economics and Management Sciences, Crn Lynwood and Roper street, 0002, Pretoria, South Africa. Email mchitiga@postino.up.ac.za

3 Ramos Mabugu, Centre for Environmental Economics and Policy in Africa, Department of Agricultural Economics, University of Pretoria, 0002 Pretoria, South Africa. Email rmabugu@postino.up.ac.za

4 Tonia Kandiero, National Treasury, Private Bag X115, Pretoria, South Africa. Email Tonia.Kandiero@treasury.gov.za. or tkandiero@absamail.co.za. This work started when I was at University of Pretoria. The findings, interpretations, and conclusions expressed in this paper are those of the authors and do not represent the views and policies of the National Treasury. 


\title{
A computable general equilibrium micro-simulation analysis of the impact of the removal of tariffs on poverty in Zimbabwe ${ }^{1}$.
}

\begin{abstract}
The paper uses a micro-simulation computable general equilibrium (CGE) model to study the impact on poverty of a complete removal of tariffs in Zimbabwe. The model incorporates 14006 households derived from the 1995 Poverty Assessment Study Survey. This paper's novelty is that it is one among a small group of papers that incorporates individual households in the CGE model as opposed to having representative households. Using individual households allows for a comprehensive analysis of poverty. The complete removal of tariffs favours exporting sectors. Poverty falls in the economy while inequality hardly changes. The results differ between rural and urban areas.
\end{abstract}

JEL Classification: C68, D31, D58, I32

Keywords: Computable General Equilibrium, Trade Liberalisation, Micro-simulation, Poverty, Inequality.

\footnotetext{
$1 \quad$ Author Posting.

(c) Taylor

\& Francis,

This is the author's version of the work. It is posted here by permission of Taylor \& Francis for personal use, not for for redistribution.

The definitive version was published in Journal of Development Studies, Volume 43 Issue 6, August 2007. doi:10.1080/00220380701466666 (http://dx.doi.org/10.1080/00220380701466666)
} 


\section{Introduction}

There is an ongoing debate on the role of trade policies in alleviating poverty. Winters et al. (2002), Reimer (2002) and Rajan and Bird (2002) give a comprehensive literature review on the impact of trade liberalization on poverty and the economy. Reimer (2002) summarizes the main links between trade and poverty from the Winters (2000) paper and concludes that there is no simple generalization about the relationship between trade liberalization and poverty, and that it is difficult in one study to take into account all these linkages. It does seem though that there is no strong evidence that trade liberalization will increase poverty or vulnerability but there are no guarantees either that the poor will always benefit. An important question is therefore, the extent to which poverty in Africa can be attributable to trade liberalisation. Using the example of Zimbabwe, this paper explores how successful trade liberalisation has been in alleviating poverty and improving income distribution.

Zimbabwe implemented a comprehensive trade liberalization programme in 1991 which reversed a long tradition of dirigisme. Import controls, industrial licensing and fixed exchange rates associated with the previous period were dismantled. Despite the serious drought in 1991-1992, the liberalisation policy was not reversed. The aggregate response of trade to the opening up was quite dramatic. Total trade rose from 45 per cent of GDP in 1988 , to more than 100 per cent ten years later. While it is generally agreed that the programme significantly altered the contours of the Zimbabwean economy, it is also possible that the programme could have sharpened inequality and increased poverty. Poverty has been on the increase, particularly since the implementation of the structural adjustment program in 1991 leading people to blame the reforms for the increased poverty. For the reader who is more interested in trade policy effects than Zimbabwe, the 
question is whether Zimbabwe's experience is an inevitable consequence of trade liberalization or whether it is simply a result of 'local' mismanagement. This paper will attempt to show that, while the last of these reasons is important, there are lessons to be drawn by a wider audience.

This paper aims to establish the longer-term impact of trade liberalisation, through a complete removal of tariffs, on incomes, poverty and inequality in Zimbabwe. We use tariffs as the main instrument for reform rather than quantitative restrictions, mainly because we are interested in analysing the classic trade effects. Further, our objective is to analyse the links between poverty and tariff reductions. This simulation is important because it allows us to see the effects that tariff policy could have had on poverty and inequality had all the other events happening at the same time been held constant. These counterfactual effects are interesting because they show us whether the after shock effects that occurred are due to the policy or other influences in the economy such as inflexible adjustment of labour and capital, and skill biased technical change. Indeed, Zimbabwe is a country that has been badly affected by politics in the last several years and it is therefore interesting to present a counter-factual picture of what could have happened assuming the maintenance of the pre-crisis structure.

To construct the counterfactuals, we use a computable general equilibrium (CGE) model that is benchmarked to the 1995 social accounting matrix (SAM) data. This baseline has been selected for several reasons. First, we would like to analyse tariff removal and not any other quantitative barriers to trade. By 1995, most of the quantitative barriers had been removed and tariffs had become the main instrument of trade policy. Second, the microsimulation data is obtained from a 1995 household survey and this makes it easily 
conformable for use with a 1995 SAM. Lastly, given the economic disruptions that are linked to the recent land reform policies, the year 1995 is one of the latest stable years to work with in Zimbabwe. In thinking about these issues, it is useful to realize that the majority of CGE models used in poverty and inequality analysis are aggregated CGEs with representative households used to infer changes on income distribution due to trade liberalisation. In such models, not much can be done in terms of poverty analysis since, by its nature, the study of poverty relies on micro data. To overcome this limitation we replace the assumption of a representative household by incorporating all the households from a nationally representative survey. In this way, we endogenise intra-group variations. To our knowledge there is no work yet that looks at poverty and trade at the household level in a CGE model in Zimbabwe.

The rest of the paper is arranged as follows. We first discuss some relevant country background pertaining to trade liberalization and poverty in section 2 . Section 3 develops the methodology used while the following section presents the simulation and results. The final section concludes.

\section{Trade liberalization in Zimbabwe}

Trade liberalisation in Zimbabwe was launched under the auspices of a broader set of measures referred to as the Economic Structural Adjustment Programme (ESAP). The trade liberalisation that was undertaken between 1991 and 1997 was meant to shift the economy from the rationed allocation of foreign currency of the 1980s, to market based access. Import controls, industrial licensing and fixed exchange rates of the previous regime were dismantled first in the early 1990s, while tariff reduction was completed by 1997. Before the liberalisation period, tariffs were used mainly as an instrument to raise 
revenue with the role of protection of industry being assigned to other import and exchange controls. This, however, changed after liberalisation because most of the important quantitative trade restrictions had been removed by 1994. In 1997 a new tariff structure was launched (see Table 1). The major contribution was a reduction in the rates and a rationalisation of band structures. The other aim was to lower duties on raw materials and other inputs in an effort to reduce tariff payment evasion that had been rife before that period. Some major policy reversals though have since occurred with some rates being increased and others lowered further, particularly in the new millennium due to pressing balance of payments problems.

Table 1: Structure of tariff rates

\begin{tabular}{|l|l|l|}
\hline Goods & $\begin{array}{l}\text { Previous rates of duty (before } \\
1997)(\%)\end{array}$ & $\begin{array}{l}\text { New rates of duty (from } \\
1997)(\%)\end{array}$ \\
\hline Raw materials & $0-40$ & 5 \\
Merit goods: & $0-40$ & 5 \\
-Education & $0-20$ & $0-20$ \\
-Medical & $0-10$ & 0 \\
-Goods for the blind & $0-25$ & 0 \\
Capital goods & $0-20$ & $5-15$ \\
Tools & $0-56$ & 15 \\
Spares & $0-55$ & 15 \\
Partly Processed Inputs & $0-35$ & $20-30$ \\
Intermediate goods & & $40-85$ \\
consumables and & $0-85$ & \\
Finished goods &
\end{tabular}

Source: (Reserve Bank of Zimbabwe, 1997 p20).

Neglecting adjustment problems, trade liberalisation should lead to an acceleration of growth and productivity through greater allocative efficiency and better resource allocation. In the case of Zimbabwe, the growth rate was higher at 4.2 per cent during the 1980s than during the Unilateral Declaration of Independence era (1971-79) (4.1 per cent) and during 1991-2000 (0.3 per cent). In 1999 GDP growth was flat, fell deeply between 2000 and 2005 and an even bigger fall is forecast for the next few years at least. 
Over the period 1990 to 1998 , the annual projected growth in population was an average of 2.6 per cent which was higher than the economic growth rate of 0.3 per cent. As a result, per capita GDP growth was declining and this implies declining living standards. This, in turn, has serious implications for poverty.

A broad analysis of the performance of exports in the regulated, transition and liberalized periods suggests that the reforms may have stimulated export growth. Total exports grew steadily from slightly over Z\$5 billion in 1991 to a little over Z\$25 billion in 1996 (Reserve Bank of Zimbabwe, 1997). During the pre-adjustment period (1981-1990) the US\$ value of exports grew by only 2.4 per cent per annum. Between 1994 and 1998 export growth averaged 5 per cent per year. The rate of growth was reversed in 1997 and there was a substantial decline in 1998. This downturn continued through the new millennium. Imports also grew steadily from Z\$5 billion in 1991 to Z\$20 billion in 1996 (Reserve Bank of Zimbabwe, 1997). In 1990, the manufacturing sector contributed 22.8 per cent of GDP and by 1996 this had declined to 20.7 per cent and to 17.1 per cent by 1998. In the ESAP period from 1991 to 1996 , overall real GDP declined by 3.8 per cent. The decline in the manufacturing sector alone accounted for most of this. If it were not for positive growth in finance and other sectors, GDP would have fallen by more than 3.8 per cent (Bhalla et al. 1999). After 1994, although there was positive growth in GDP (11.9 per cent increase up to 1998), with most sectors growing, the manufacturing sector continued its decline. This suggests that the falling share of manufacturing can be interpreted as de-industrialization rather than simply relative shifts in sector sizes (Bhalla et al. 1999).

Poverty increased in the 1990s after the onset of the reform programme (World Bank, 
1998). The Central Statistics Office (CSO)'s Income, Consumption and Expenditure Survey (ICES) of 1990-1991 and 1995-1996 are some of the major sources of most estimates on poverty and income inequality. The World Bank (2004) reports that the prevalence of extreme poverty increased from 25 per cent in 1991 to 35 per cent by 1995. The 1995 Poverty Assessment Study gives comprehensive figures based on their survey for 1995 and their own calculated poverty line (Poverty Assessment Study Survey (PASS), 1996). The PASS survey found that, for 1995, poverty was more prevalent in rural areas with 75 per cent of households in the total poor category compared to 39 per cent in the urban areas. The highest incidence of poverty in 1995 was in the communal areas (84 per cent of households), followed by the resettlement areas and small-scale commercial farms (70 per cent), large-scale commercial farms (57 per cent) and urban areas (39 per cent). Rural areas had the highest distribution of all classifications of poverty as shown in Table 2 below.

As might be expected, the poorest households were those without employment, and the least poor were those that owned businesses and were themselves employers (PASS, 1996). In terms of skill, the survey results showed that the unskilled workers were the poorest.

Table 2: Households per cent distribution of poverty by region, 1995

\begin{tabular}{|l|c|c|c|}
\hline & Very poor \% & Poor \% & Non poor \% \\
\hline National & 45 & 16 & 39 \\
\hline Rural & 60 & 15 & 24 \\
\hline Urban & 21 & 18 & 61 \\
\hline
\end{tabular}

Source: Table 3.2 PASS (1996) 
The land reform policies and land invasions from 2000 onwards have greatly disrupted the economy. The agricultural sector which had traditionally been the main contributor to growth (contributing more than 60 per cent of the foreign currency in the 1990s), has been severely affected by the disturbances on the farms. The land reforms not only led to reduced output due to uncertainty but reduced output due to lack of resources and expertise on the part of the new farmers. The droughts that have occurred in most of the years since the reforms have contributed to making things worse. Agriculture's contribution to the economy has since fallen drastically.

With a Gini coefficient of 57.83, Zimbabwe ranked fifth in inequality in 1990 out of a total of 108 developing countries. There are several lines along which inequalities occur in Zimbabwe. Some of the main ones are along racial lines, along urban and rural dwelling, along ownership of factors of production, and along skill. The CSO found that in $1990 / 1991$, the greatest inequality was measured in communal areas using the Theil index (CSO, 1995). It is here that the majority of Zimbabweans reside. Generally, it is agreed that inequality has been on the increase since the beginning of the reforms. For instance, the share of GDP going to wages and salaries fell from 57.3 per cent in the late 1980s to 45 per cent in the first half of the 1990s while that of profits went up between the two periods. Thus, more poverty and income inequality was witnessed after the reform period.

\section{Model development}

\section{A review of related models}

There has been some previous work on Zimbabwe focusing on the role of trade policy in influencing growth, income distribution and indirectly affecting poverty (Davies et al. 
1994, 1998; Rattsø and Torvik, 1998; Bautista et al. 1998; Mabugu, 2001; ChitigaMabugu, 2001). As in most other places elsewhere in the world, these models use the representative household assumption and thus can only give results pertaining to average changes in income distribution after policy shocks.

The studies have each different angles, different type of trade liberalisation and different specification. The Davies et al. $(1994,1998)$ model is the basis of the models by Rattsø and Torvik (1998), Mabugu (2001) and Chitiga-Mabugu (2001). This is a static CGE model using data from 1985. Among other specifications, trade is characterised by foreign currency rationing rules and a fixed exchange rate. There is a shortage of foreign currency explicitly specified in the model reflecting the situation in the economy at that time. Most of the trade liberalisation experiments are variations of removal of rationing rules and devaluation of the Zimbabwean dollar while in Mabugu (2001) the consequences of reduction in trade taxes is explored. For Rattsø and Torvik (1998), trade liberalisation is characterised by the removal of foreign currency rationing in different stages and not by removal of tariffs. They found that, in the short run, there was a contraction of output and employment after that type of trade liberalisation. They also find that there was a consumption boom as people ran down previously forced savings leading to a rising trade deficit. They used four income distribution groups and generally found that this type of trade liberalisation favoured the richer groups.

Bautista et al. (1998) offered a different version to these models. They use a SAM for 1991, a period marking the beginning of structural adjustment policies in Zimbabwe. They assume a fixed exchange rate and an endogenously determined current account balance to reflect the reality of the base year for their SAM. They also have quantitative 
import restrictions caused by rationing rules. They simulate among several other experiments a policy of trade liberalization. Trade liberalization in Bautista et al. (1998) is an experiment or removal of non-tariff barriers, substantial lowering of the tariff rate to a lower uniform rate and removal of foreign exchange controls. This was an experiment directly related to the events of this period of structural adjustment. They find that trade liberalization benefits all groups in the economy although the benefits to the poorest majority group is the least.

In the past few years there has been growth of studies on trade liberalisation and poverty and income distribution using CGE models. Generally there are several approaches that have been used to study these issues (for a summary see Davies, 2003). The traditional method is to use an aggregated CGE with representative households to infer changes on income distribution due to trade liberalisation. In such models, not much can be done in terms of poverty analysis since, by its nature, the study of poverty relies on micro data. As a result of this limitation, there have been attempts to try and pay attention to as much income distribution and poverty data as possible by greatly disaggregating the household types (see for example Piggott and Whalley, 1985). However, even in such studies comprehensive poverty analysis is not permitted.

As a response to this shortcoming of standard CGE models, various authors have gone back to earlier work by Adelman and Robinson (1979) of assuming a distributional form for the income and using this to estimate poverty changes after a simulation. Demery and Demery (1991) used a lognormal distribution to analyse the poverty impacts of policies. Decaluwé et al. (1999) have used a Beta function as opposed to the lognormal distribution because it is more flexible. A similar type of study was done by Stifel and 
Thorbecke (2003). These studies show that there is much in terms of poverty and inequality analysis that can be done using this type of analysis. In all the above cases, the traditional CGE is only linked to the micro data after the simulation. Thus the representative household assumption is maintained and there is no consideration of intragroup distributions which allows for an in depth analysis of poverty. To capture as much heterogeneity as possible among households, one needs to use micro-simulation approaches whose history dates back to Orcutt (1957). The particular form of microsimulations relevant for this paper is the one where one incorporates household data into the CGE model and simulates the model with all the individual households (see Cogneau and Robilliard, 2000).

Such an approach was used by Cockburn (2001) who looks at trade liberalization and poverty in Nepal. The assumption of a representative household is replaced by incorporating all the households from a nationally representative survey. In this way, the study endogenises intra group variations. The households in the model are characterized by their sources of income and consumption patterns. Cockburn's findings lends support to the view that micro simulations are very important for poverty analysis. Cororaton (2003) has also used the same methodology for the Philippines with 24,797 households and succeeded in carrying out a comprehensive poverty and income distribution analysis.

Decaluwé et al. (1999) give a comparison of results of poverty and income distribution using three main types of methods: traditional CGEs with representative households; use of household data or other forms to infer the distribution of each representative household; and the use of household data into the CGE model itself. Their comparisons show that the last mentioned methodology of micro-simulation is superior to all the 
others in terms of a comprehensive analysis of poverty and thus, it is a worthwhile exercise for poverty analysis. These results are also confirmed by the work of Savard (2004).

\section{Model description}

Broadly speaking there are two kinds of CGE models that are usually applied to tariff analysis. The first group can be traced back to applied welfare economics and is largely an attempt to make operational Walras's general equilibrium framework. At the heart of these models are neoclassical theories of the firm and household behaviour. The objective of Walrasian CGE analysis is to quantify the effects of tariff changes on the optimal allocation of resources, on efficiency and on welfare. The second variety of CGE models applied to tariff analysis are what can be termed macro-CGEs. The objective here is typically to quantify short run rigidities such as those found in factor markets, income distribution consequences, sectoral growth and trade balance effects than to focus exclusively on resource allocation effects of tariff policy. The understanding in this paper is that macroeconomic issues such as unemployment add to the welfare and poverty debate and therefore macro-CGE's add to our understanding of tariff policy reforms. However, they can cloud the debate and strictly speaking, can take us outside the realm of efficiency (in resource allocation) and welfare in attempting to understand effects of policy on poverty. For this reason, the model used in this paper is largely in the former tradition because the aim is to take into account welfare and poverty analysis in the broader sense where it is about resource allocation and distribution ('actual' as opposed to representative agents). As well, we look at the rather longer run effects of policies and largely ignore the short run rigidities that would necessitate using a macro-CGE model 
that accounts for rigidities and other short run frictional issues. We see the effects of trade policies on poverty as largely long run rather than short run issues.

The model used is based on the EXTER+ model (see Decaluwé et al. 1999; Cockburn and Cloutier, 2002; and Cockburn et al. 2004). The model is calibrated to a 1995 SAM for Zimbabwe (Chitiga et al. 2000). The model has 16 production sectors and activities as shown in Table 3. Eight of these sectors are agricultural based while 4 are manufacturing based. There is a mining sector and 3 services (including electricity). The model uses 4 factors of production namely, skilled labour, unskilled labour, capital and land. The model incorporates 14006 households. These households are derived from the 1995 Poverty Assessment Study Survey (PASS). The income and expenditure data for the survey was extracted and reconciled to the SAM sectors, institutions and factors of production.

Table 3: Sectors included in the model

\begin{tabular}{|l|l|}
\hline $\begin{array}{l}\text { Name used in GAMS code and } \\
\text { reporting }\end{array}$ & Meaning of the name \\
\hline Agrain & Grain crops \\
\hline Ahoticu & Horticulture crops \\
\hline Ateacoffe & Tea and coffee \\
\hline Acottobc & Cotton and tobacco \\
\hline Alivestock & Livestock \\
\hline Afishery & Fishery \\
\hline Aforestry & Forestry \\
\hline Amining & Mining \\
\hline Afoodproc & Food processing \\
\hline Atextile & Textile \\
\hline Allothemauf & All other manufacturing \\
\hline Aconstrn & Construction \\
\hline Aewtdts & Water, electricity and other trade services \\
\hline Apubsv & Public services \\
\hline Aprivsv & All other private services \\
\hline &
\end{tabular}


The model makes use of nested production functions. Total production is determined by a Leontief function between value added and intermediates at the top level. Intermediate demand by sectors is also modeled as a Leontief function. The produced commodities are all sold through the market. The factors of production are modelled as a CES function between capital and labour. Firms aim to minimize costs and through this determine their factor demands. In the agricultural sector, land is also included in the CES function between the composite factor (capital and labour) and land. Labour is modelled as a CES function between skilled and unskilled labour. Capital and land are fixed in aggregate, and capital is freely mobile across sectors. The labour market closure is that labour is freely mobile between sectors, its volume is given and wages for each skill type adjust to clear the market.

The nominal exchange rate is taken as the numéraire. All other prices are variable. The local price is made up of the producer price plus indirect tax. The import price and the domestic price then form the composite price for the sectoral composite commodity. The local import price is the world price adjusted by the exchange rate and import taxes. The experiment of removing import taxes will thus have an impact on the composite price. Output price affects the export price and is itself affected by input prices.

The produced output is an aggregate output sold in the domestic market or in the export market. At this stage there is imperfect transformation of the aggregate good into exports and domestic goods given by a constant elasticity of transformation (CET) function. Producers seek to maximize the revenue from their sales given the constraint in the transformation. Export demand is assumed infinitely elastic. The price received by 
producers is given in local currency. In the domestic market the good is sold to households, the government and used for investment and intermediate inputs. Domestic prices are flexible and they equilibrate the demand and supply of the different commodities. In the domestic market there are also imported commodities. These are combined in a CES function to form a composite commodity in each sector (Armington, 1969). International supply of imports are assumed to be perfectly elastic at the given world prices. These Armington specifications allow for two way trade as well as some degree of independence in domestic prices, which reflects the real situation of many countries.

Institutions consist of households, government, firms and the rest of the world. Households receive the bulk of their income from ownership of the factors of production. They also receive income transfers from the government, firms, other households and the rest of the world. They spend their income on payment of taxes, transfers to other institutions, savings and then on consumption of commodities. While average propensity to save is constant, we add an auxiliary variable that allows savings to adjust to given investment levels. Consumption demand is specified as a linear expenditure system obtained from maximizing a Stone Geary utility function. The calibration of minimal consumption is performed with the help of the income elasticity and the Frisch parameters, after first carrying out an adjustment of the elasticities to ensure that they respect Engel aggregation in the LES demand system. All households are assumed to have the same utility function. Enterprises receive income from capital and transfers from other institutions. They pay taxes, save and transfer income to other institutions but do not consume sectoral output. 
The model contains 14006 households derived from a nationally representative survey of 1995. The expenditure and income data for each household are extracted and linked to the macroeconomic data. Instead of having a few representative households, we have all the households from the survey scaled up to the national population. This data now forms part of the social accounting matrix and is used directly to calibrate parameters and to solve the CGE model. We are then able to trace the impacts of policies on each household as these would be impacted differently depending mainly on their various sources of income and patterns of expenditure. After the simulation, the before and after simulation expenditure is then compared to check how poverty and inequality have changed following a policy simulation.

The government receives taxes from institutions, commodities and activities. These taxes are given as fixed ad valorem rates. Direct taxes apply to enterprises and rich households. Government expenditure is on commodities and on transfers to other institutions. All transfers to households are fixed shares. The government expenditure is fixed. When import taxes are removed this has government revenue consequences. How the government responds to this is obviously very important. In line with most welfare analysis in public finance, we have chosen to make public savings exogenous so as to avoid analyzing the welfare impacts of government spending. The revenue that is sufficient to attain the given level of government spending can be reached through adjustment of direct taxes on household income. Thus, direct tax is instituted to compensate for the decline in revenue following a removal of import tariffs.

Total investment and the current account deficit are fixed and this has the effect of ruling out possible occurrences of a 'free lunch' outcome from unlimited international inflows. 
The model is square in the sense that the number of equations is equal to the number of variables. It is solved as a system of simultaneous non linear equations. The model reflects a Walrasian economy that solves for relative prices.

\section{Simulation results}

The simulation conducted is a total removal of import tariffs. We present the sectoral and macro results of this experiment first. It is important to understand some of the base year statistics in order to understand the results. For instance, we see in Figure 1 that three of the agricultural sectors were subjected to tariffs as well as all tradable manufacturing, mining and private services. We expect these sectors therefore to be directly affected by the fall in the price of imports induced by a tariff removal. Table A1 in the Appendix also shows various base case sectoral shares of imports, exports and total output. We see, for instance, that the sector 'all other manufacturing' has the largest share of imports while tobacco has the largest share of exports. Most agricultural goods are exported with almost all tobacco, tea and coffee being exports. We also see that the largest contribution to value added is the tertiary sector followed by the industrial sector and then the primary sectors.

We expect that the simulation will affect prices of imports directly. This will in turn affect all other prices due to interlinkages that exist in the economy. Most domestic prices are likely to fall leading to a switch to export production. At the same time there is likely to be a switch to imported commodities. The production structure will thus change, thereby changing the incomes of the institutions in the model. The gaining sectors, such as export oriented sectors will benefit those whose factors are used intensively in their production. On the other hand the sectors whose goods are being substituted by imports 
are likely to reduce production, thereby adversely impacting on the factors that they use intensively and their owners. These income effects together with induced price effects ultimately determine the poverty outcome. Depending on which sectors experience price reductions, those households who spend a greater proportion of their income on these will benefit. As the poor normally devote a larger share of their income to food, it is especially important to find out what happens to the prices of food after the simulation.

As expected, the initial effect of the experiment is to reduce all import prices in local currency by an overall 10.9 per cent. As a result, imports go up overall by 4.9 per cent. Figure 1 shows that the sectoral import price effect is related to the initial tariff.

Figure 1: Initial tariff rates (tm) and the resulting fall in import prices (PMi) after the shock.

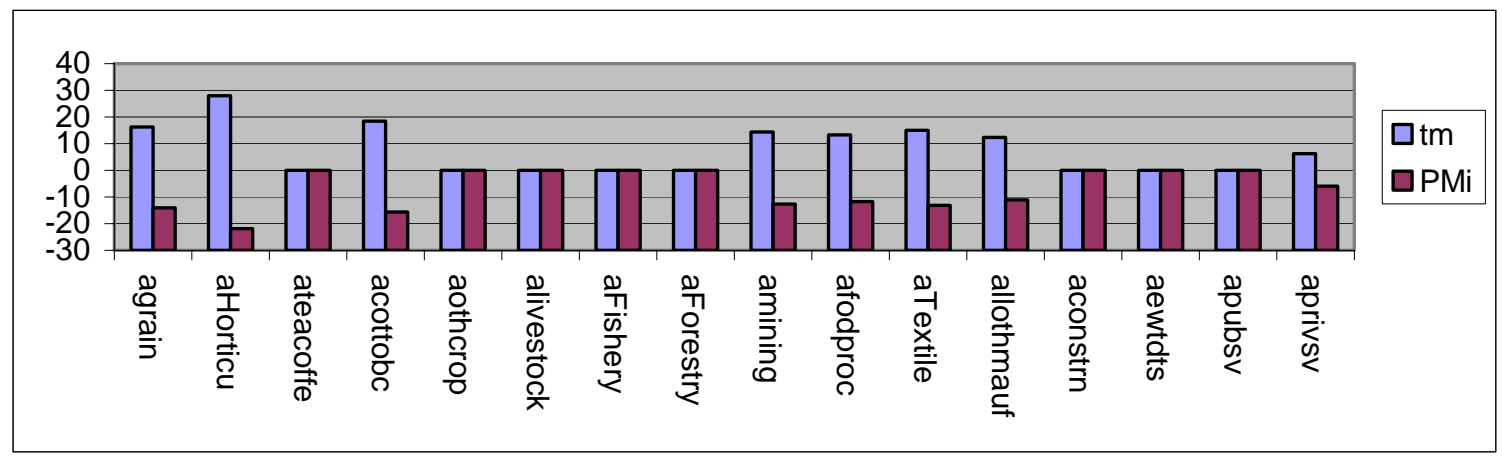

Source, SAM 1995 (Chitiga et al. 2000).

The higher the initial tariff, the higher the associated fall in price. The main beneficiaries in terms of increased imports are the sectors that had previously high protection such as horticulture (39 per cent) and grain (21.3 per cent). It should be mentioned however, that except for manufacturing sectors, imports contribution to total output in most other sectors is quite low as seen in Table A1. Thus the output effects and price advantages from reduced tariffs are also affected by this. The increase in imports, which implies a 
reduction in domestic demand, forces domestic prices to fall. However, in the agriculture sectors there is a reallocation of resources to the export-oriented sectors leaving the grain and livestock sectors with much less production than before. The result of this reduced output puts pressure on prices in these sectors, thereby increasing the price of food. However, for most other sectors, the domestic prices fall as seen in Table 4.

Table 4: Simulation results

\begin{tabular}{|c|c|c|c|c|c|c|c|}
\hline Sectors & $\begin{array}{r}\text { Domestic } \\
\text { price }\end{array}$ & $\begin{array}{r}\text { Producer } \\
\text { price }\end{array}$ & Value added & $\begin{array}{r}\text { Skilled } \\
\text { wage rate } \\
\end{array}$ & $\begin{array}{r}\text { Unskilled } \\
\text { wage rate }\end{array}$ & $\begin{array}{r}\text { Rate of } \\
\text { return on } \\
\text { capital } \\
\end{array}$ & $\begin{array}{r}\text { Rate of } \\
\text { return on } \\
\text { land } \\
\end{array}$ \\
\hline Agrain & 0.3 & 0.4 & -3.6 & -11.4 & 10.4 & -6.2 & 2.7 \\
\hline AHorticu & -0.7 & -0.6 & -3 & -11.4 & 10.4 & -6.2 & 2.7 \\
\hline ateacoffe & -8.2 & -2.5 & 5.8 & -11.4 & 10.4 & -6.2 & 2.7 \\
\hline Acottobc & -12.3 & -3.1 & 11.8 & -11.4 & 10.4 & -6.2 & 2.7 \\
\hline aothcrop & -2.2 & -1.1 & -0.4 & -11.4 & 10.4 & -6.2 & 2.7 \\
\hline alivestock & 0.8 & 0.8 & -4.3 & -11.4 & 10.4 & -6.2 & 0 \\
\hline aFishery & -4.2 & -4.2 & -2.1 & -11.4 & 10.4 & -6.2 & 0 \\
\hline aForestry & 1.1 & 1.1 & -1.8 & -11.4 & 10.4 & -6.2 & 0 \\
\hline Amining & -7 & -4.1 & 1.8 & -11.4 & 10.4 & -6.2 & 0 \\
\hline afodproc & -3.5 & -3.2 & -3.4 & -11.4 & 10.4 & -6.2 & 0 \\
\hline Atextile & -2 & -1.7 & -5.8 & -11.4 & 10.4 & -6.2 & 0 \\
\hline allothmauf & -5.8 & -4.6 & -2.6 & -11.4 & 10.4 & -6.2 & 0 \\
\hline aconstrn & -4 & -4 & -2.6 & -11.4 & 10.4 & -6.2 & 0 \\
\hline Aewtdts & -3.1 & -3.1 & -0.6 & -11.4 & 10.4 & -6.2 & 0 \\
\hline Apubsv & -6.7 & -6.7 & 0.2 & -11.4 & 10.4 & -6.2 & 0 \\
\hline Aprivsv & -4.3 & -3.2 & 1.5 & -11.4 & 10.4 & -6.2 & 0 \\
\hline
\end{tabular}

The result of reduced domestic prices against given export prices is that the export market becomes more competitive than the local market. All previous major exporters, such as tobacco and cotton, some manufacturing, mining and private services increase their exports. In terms of total output, only some agriculture sectors, such as cotton and tobacco (11.8 per cent), tea and coffee (5.8 per cent) and some mining (1.8 per cent) and private service sectors (1.5 per cent) see an increase (see Table 5). All other sectors, particularly the manufacturing sectors, end up shrinking in size after this simulation. 
Thus, trade liberalization has lead to a phenomenon similar to a de-industrialization in the manufacturing sector. The economy-wide output effect is a fall in production of 0.2 per cent.

Labour is one of the main resources in which the poor are abundantly endowed and thus, determines their status after a shock. The sectors that show an increase in labour demand after this experiment are mainly primary and tertiary. These sectors use more unskilled workers than the sectors which have shrunk. We thus expect an increase in demand for this type of labour and a fall in demand for skilled labour. The prices of the factors move to equilibrate the labour market and the results in Table 4 show that the increase in demand for unskilled labour works to increase its price (10.4 per cent), while the reduced demand for skilled labour leads to a fall in the price (-11.4 per cent) of this factor. Land values increase because of the increase in some of the agricultural sectors. This tends to reduce the demand for the factor. For capital, the shift in production away from capital intensive industries depresses demand for the factor leading to a fall in its return by 6.2 per cent as seen in Table 4. Generally, we see that the experiment leads to a reallocation of resources from other sectors to the export sectors, mainly agriculture and mining. The results suggest benefits especially for agricultural farmers that produce export oriented crops and the factors of production that they use.

Table 5: Simulation results

\begin{tabular}{|c|c|c|c|c|c|c|c|}
\hline \multicolumn{8}{|c|}{ Changes in factor demands, exports and domestic production } \\
\hline Sectors & $\begin{array}{r}\text { Skilled labour } \\
\text { demand }\end{array}$ & $\begin{array}{r}\text { Unskilled } \\
\text { labour } \\
\text { demand } \\
\end{array}$ & $\begin{array}{r}\text { Capital } \\
\text { demand }\end{array}$ & $\begin{array}{r}\text { Land } \\
\text { demand } \\
\end{array}$ & Imports & Exports & $\begin{array}{r}\text { Domestic } \\
\text { production }\end{array}$ \\
\hline Agrain & -10.4 & -7.3 & 3.4 & -4.7 & 21.3 & -3.4 & -3.6 \\
\hline Ahorticu & -9.1 & -5.9 & 2.3 & -5.7 & 39 & -1.7 & -3.0 \\
\hline Ateacoffe & 6.9 & 10.7 & 6.9 & -1.5 & 0 & 7.8 & 5.8 \\
\hline
\end{tabular}




\begin{tabular}{|l|ccccccc|} 
Acottobc & 12.8 & 16.8 & 13 & 4.1 & 1.8 & 13.6 & 11.8 \\
Aothcrop & -4.4 & -1.0 & 3.4 & -4.8 & 0 & 1.0 & -0.4 \\
Alivestock & -11.4 & -8.3 & 3.0 & 0 & 0 & -4.4 & -4.3 \\
Afishery & -4.4 & -1.1 & -1.4 & 0 & 0 & 0 & -2.1 \\
Aforestry & -9.2 & -6 & 5.5 & 0 & 0 & 0 & -1.8 \\
Amining & 3.5 & 7.1 & 1.0 & 0 & 6.7 & 6.6 & 1.8 \\
Afodproc & -1.5 & 2.0 & -3.7 & 0 & 10.1 & 1.2 & -3.4 \\
Atextile & - & -16 & -2.7 & 0 & 12.3 & -2.7 & -5.8 \\
Allothmauf & -2.6 & 0.8 & -3 & 0 & 4.2 & 3.7 & -2.6 \\
Aconstrn & -2.8 & 0.6 & -3.4 & 0 & 0 & 0 & -2.6 \\
Aewtdts & -1.6 & 1.8 & -0.5 & 0 & 0 & 0 & -0.6 \\
Apubsv & 1.0 & 4.5 & -2.2 & 0 & 0 & 0 & 0.2 \\
Aprivsv & -0.2 & 3.3 & 2.1 & 0 & 2.3 & 5.3 & 1.5 \\
\hline
\end{tabular}

The income distribution impact on the households varies depending on their sources of income and composition of expenditures. The generally well off households relying on skilled labour and capital income have been hit the hardest by this policy reform. Those reliant on unskilled incomes benefit through increased income. On the other hand, it may be expected that farmers in the rural areas have benefited from this policy because their incomes have gone up. However, we must be careful to recall that rural households are very diverse in that there is a small group of large scale farmers coexisting with a large group of communal farmers. Although the land reform process would have somewhat affected this mid-nineties picture, we expect that the general picture would still be a case of many small communal farmers, coexisting with a smaller number of larger more commercial oriented farmers at the end of the land reforms.

As mentioned earlier, the advantage of micro-simulation is that a further probe into the impact of the policy on poverty and inequality can be carried out. This is because we introduce household income explicitly into the model. We have thus introduced heterogeneity and dispensed with the assumption of the representative household. We compute some poverty indicators as shown in Table 6 . This is done by using the Foster, 
Greer and Thorbecke (FGT) measures to decompose poverty into the poverty headcount (population below the poverty line), poverty gap and the severity of poverty. We compute these measures using the software DAD (Duclos et al. 2002).

For the continuous case, the FGT index is defined as:

1.

$$
P_{\alpha}=\int_{0}^{z} \frac{(z-y)^{\alpha}}{z} f(y) d y
$$

Where $\mathrm{z}$ is the poverty line, $\mathrm{y}$ is income (or consumption expenditure) and $\alpha$ is the degree of aversion to poverty. The poverty headcount index, when the degree of aversion to poverty is given as $\alpha=0$, gives us the number of households below the poverty line divided by the total households in the group. This thus shows the prevalence of poverty but does not give us an indication of the degree of poverty. Poverty depth informs us on the mean shortfall of the poor's income below the poverty line. In this case $\alpha=1$ and we are able to tell the level of income transfer needed to bring all poor households to the poverty line. Finally, we calculate an index for the severity of poverty, which considers the inequality among households that are poor. In this case with $\alpha=2$, more importance is accorded to the shortfalls of the poorest households. The weight assigned to each household is equal to its shortfall from the poverty line (see also Ravallion, 1994). Using the household data consumption expenditure results, the following poverty results were found for this experiment.

Table 6 Poverty results using Normalized FGT measures

\begin{tabular}{|l|l|l|l|l|}
\hline & & & & \\
& & Base & After simulation & \% change \\
\hline Poverty head count $(\alpha=0)$ & & & & \\
\hline & ALL & 0.622 & 0.601 & -3.33 \\
\hline & & 0.005 & 0.005 & \\
\hline & Rural & 0.721 & 0.712 & -1.41 \\
\hline & & 0.005 & 0.005 & \\
\hline
\end{tabular}




\begin{tabular}{|l|l|c|c|c|} 
& Urban & 0.273 & 0.261 & -3.85 \\
\hline & & 0.008 & 0.008 & \\
\hline Poverty gap $(\alpha=1)$ & & & & \\
\hline & ALL & 0.332 & 0.320 & -3.13 \\
\hline & & 0.003 & 0.003 & \\
\hline & Rural & 0.398 & 0.389 & -2.31 \\
\hline & & 0.003 & 0.003 & \\
\hline & Urban & 0.077 & 0.074 & -4.05 \\
\hline & & 0.003 & 0.003 & \\
\hline Poverty severity $(\alpha=2)$ & & & & \\
\hline & ALL & 0.212 & 0.211 & -5.00 \\
\hline & & 0.004 & 0.004 & \\
\hline & Rural & 0.263 & 0.252 & -4.00 \\
\hline & & 0.003 & 0.003 & \\
\hline & Urban & 0.035 & 0.033 & -6.06 \\
\hline & & 0.002 & 0.002 & \\
\hline
\end{tabular}

Note: The figures in italics are standard deviations

We see from Table 6 that the removal of tariffsleads to a fall in poverty, seen through the reduction in head count, poverty gap and the severity of poverty between the base and after simulation FGT values. The fall in prices in the economy makes the consumption basket cheaper than before and the increase in incomes of the poor allows some of them to move out of poverty. Further, we notice that on comparing the changes between rural and urban areas, the greater reduction in poverty occurs in the urban areas as opposed to rural areas. The results are partly explained by the variation in commodity prices. The rural poor mainly consume grains as the main food item while the urban poor mainly consume processed food (mealie-meal) as their main food item. As seen in Table 4, the price of grain has slightly increased by $0.3 \%$ while the price of processed food has fallen substantially by $3.5 \%$. The fall in the price of horticultural goods however by $0.7 \%$, which is another major food item of the poor, is an advantage for the rural poor households mainly. However, the urban poor households benefit the most from food price reductions and this explains the larger fall in poverty for this group. 
FGT measures are quite sensitive to the choice of the poverty line. To check that for a wide range of selected poverty lines, the results are maintained, we plot the difference in the before and after simulation FGT measures for a wide range of poverty lines. We see in Figure 2 that for the full range, for all the population, poverty is reduced after the simulation. This same result was also found for poverty severity and the poverty gap measures.

Figure 2: Headcount ratio curves (FGT with $\alpha=0$ )

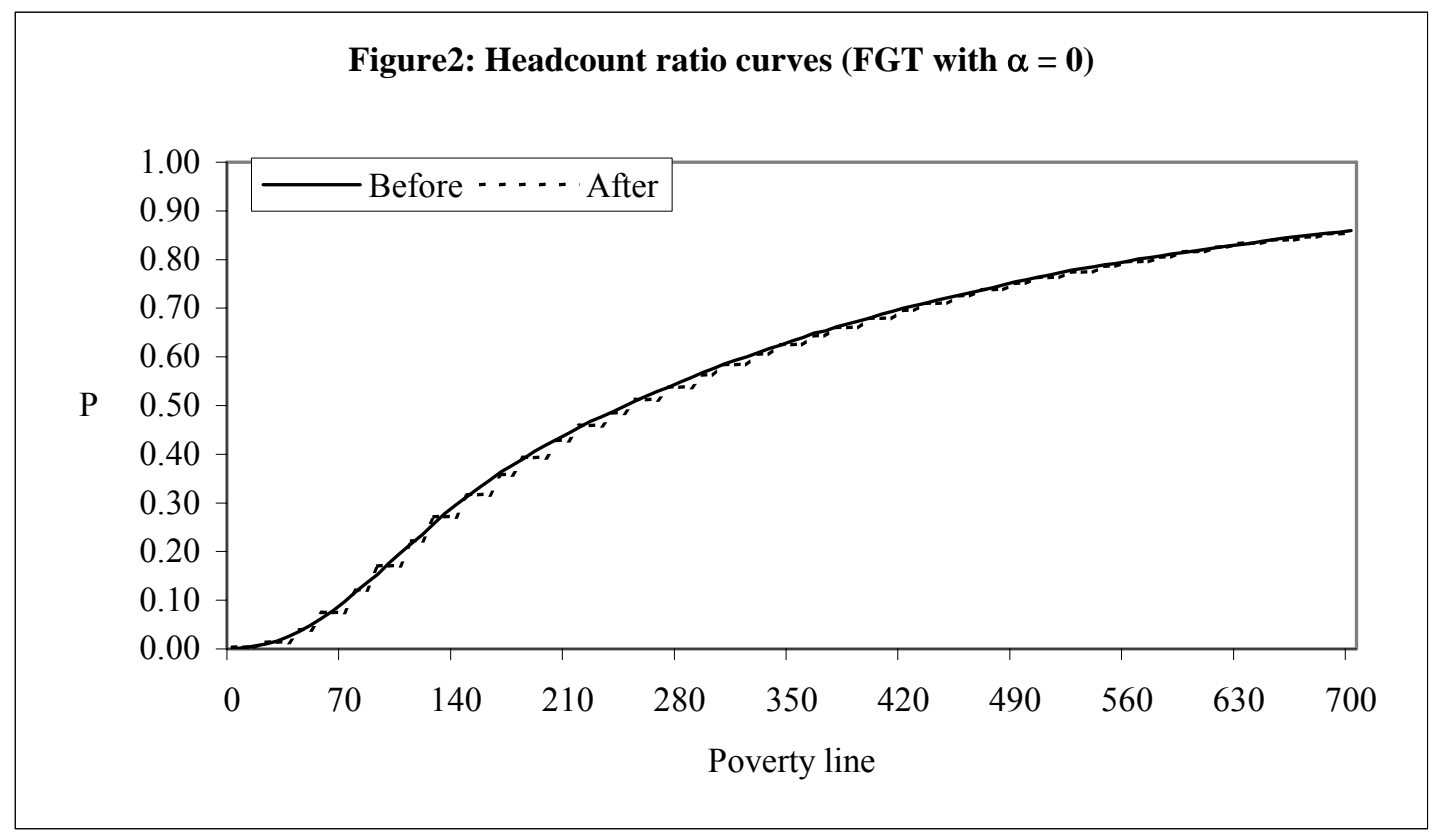

Figure 3 shows that the final choice of the poverty line matters. By looking at the variation in headcount ratio, there appears to be some increase in the number of those who are the very poor but a definite reduction in the number of those that are poor to moderately poor, who form the larger of the two groups. This confirms the result already found that in general, poverty is reduced by this trade policy reform. 
Figure 3: Variation in headcount ratio Curves (FGT with $\alpha=0$ )

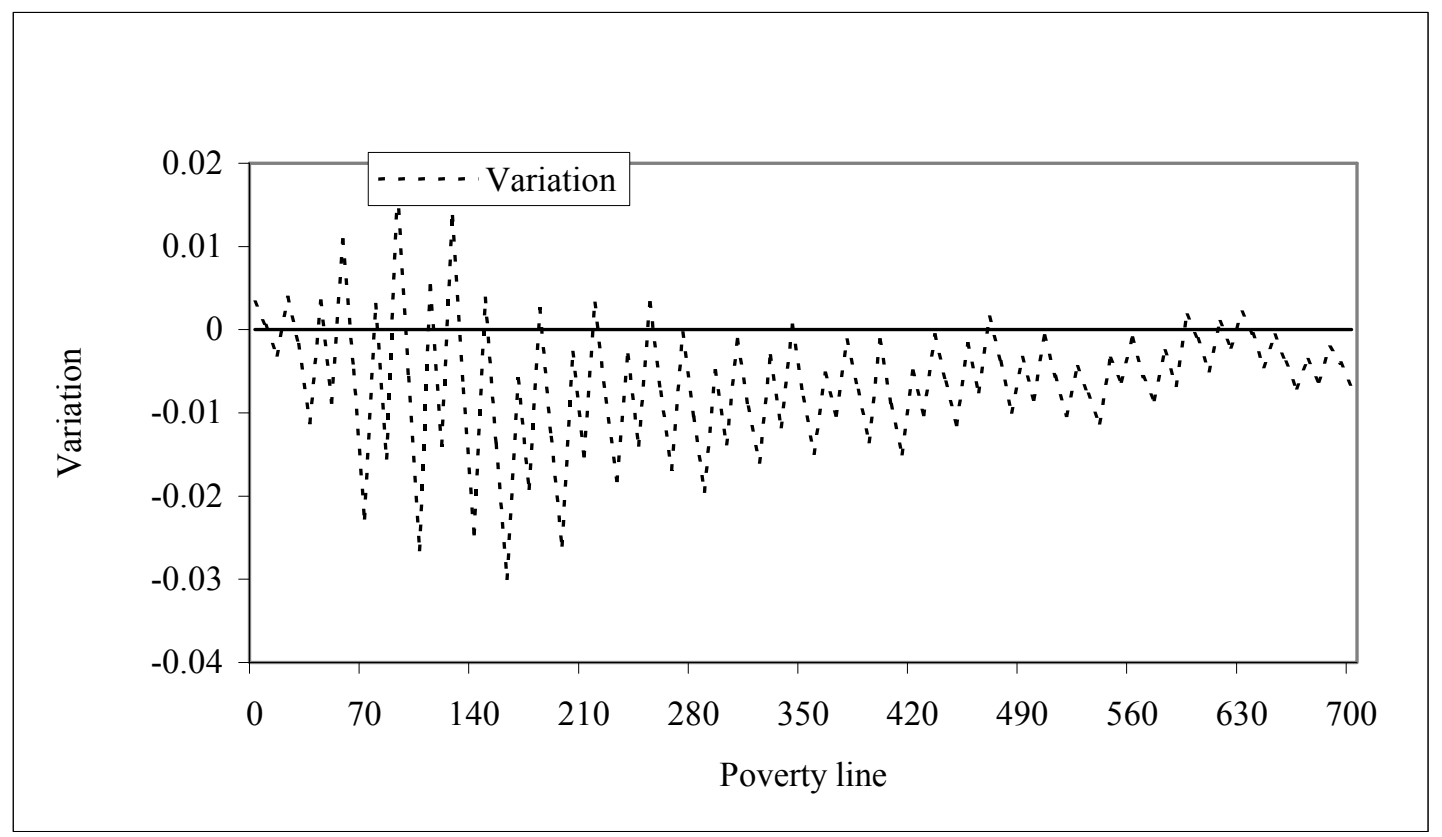

Figure 4: Variation in poverty gap curves (FGT with $\alpha=1$ )

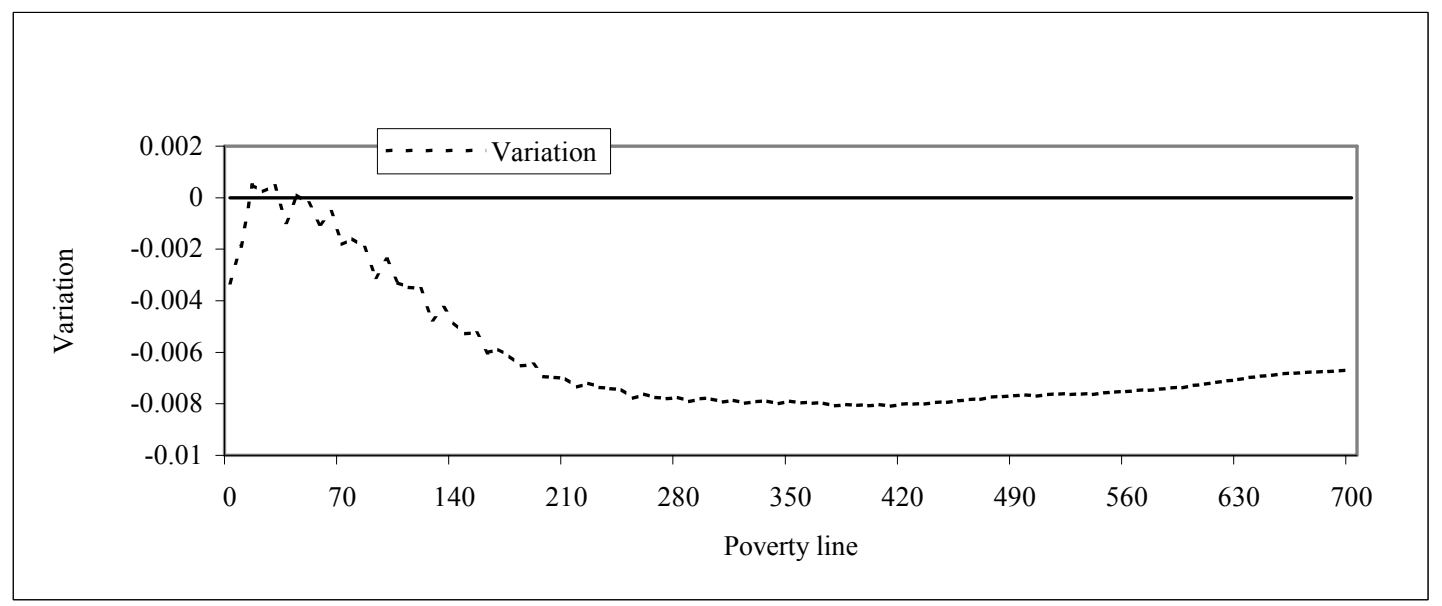

The poverty gap variations reinforce these results as seen in Figure 4 . There is only a slight increase in the poverty gap among the very poorest, but there is a fall in poverty among the rest of the poor groups. These results also carry through to the case of poverty severity confirming that poverty severity falls in the economy with trade liberalization. Next we compute inequality indexes. First we use the Gini- coefficient, whose formula is:

$$
\text { Gini }=\frac{1}{\mu N(N-1)} \sum_{i} \sum_{j}\left|x_{i}-x_{j}\right|
$$


where $\mathrm{x}$ is income (or consumption expenditure) and $\mathrm{N}$ is population.

The assumption that all capital is fully mobile between sectors means that the general reduced activity in the industrial sector dampens the return on all capital. This includes also agricultural capital. As a result even though incomes of export agriculturalists increase, their income from capital falls. This against the fact that low incomes have increased means that we expect incomes of the poor to rise while those of the rich are not increasing as much. Indeed the inequality indexes show that there is a fall in inequality although it is very small. Thus, with free mobility we see that tariff reduction will tend to slightly reduce inequality through income benefits for the poorer groups of society as seen in Table 7.

Table 7: Gini index of inequality

\begin{tabular}{|c|l|l|c|c|}
\hline & & & & \\
& & Base & After simulation & \% change \\
\hline Gini index & & & & \\
\hline & ALL & 0.603 & 0.602 & -0.500 \\
\hline & & 0.020 & 0.021 & \\
\hline & Rural & 0.616 & 0.614 & -0.330 \\
\hline & & 0.029 & 0.029 & \\
\hline & Urban & 0.479 & 0.477 & -0.420 \\
\hline & & 0.028 & 0.029 & \\
\hline
\end{tabular}

The inequality results are confirmed by the Atkinson index of inequality whose results are reported in Table 8 . This index is given by the following formula:

3.

$$
I_{e}=\left[\sum_{i=1}^{n} f\left(I_{i}\right) I_{i}^{1-\varepsilon}\right]^{1 / 1-\varepsilon}
$$


It calculates $1-\left(\mathrm{I}_{\mathrm{e}} / \mu\right)$ where $\mathrm{I}_{\mathrm{e}}$ is the uniform income level which when received by all households leads to the same total welfare as the actual income distribution. $\mu$ is then the prevailing mean income. We use both $\varepsilon=0.5$ and 0.75 to indicate different level of the society's aversion to poverty.

The results show that, inequality has either remained the same or has slightly fallen after the reforms. This is because of the improvement of incomes for the unskilled workers with a fall in capital incomes as well as skilled incomes. This inequality result is most likely driven by the factor closure. For instance, had capital not been allowed free mobility, we would have expected large scale farmers to benefit much more, than presently leading to increased inequality in the rural areas. This result tells us that in the longer run, trade liberalisation does not harm income distribution and could even improve it.

Table 8: Atkinson index of inequality

\begin{tabular}{|l|l|l|l|l|}
\hline & & & & \\
& & Base & After simulation & \% Change \\
\hline Atkinson index & & & & \\
\hline$\varepsilon=0.5$ & & & & \\
\hline & ALL & 3.300 & 3.300 & 0.00 \\
\hline & & 0.028 & 0.028 & \\
\hline & Rural & 3.560 & 3.558 & -0.04 \\
\hline & & 0.040 & 0.040 & \\
\hline & Urban & 2.077 & 2.077 & 0.00 \\
\hline & & 0.033 & 0.034 & \\
\hline$\varepsilon=0.75$ & & & & \\
\hline & ALL & 4.230 & 4.230 & 0.00 \\
\hline & & 0.028 & 0.028 & \\
\hline & rural & 4.400 & 4.400 & 0.00 \\
\hline & & 0.039 & 0.040 & \\
\hline & urban & 2.750 & 2.740 & -0.36 \\
\hline & & 0.035 & 0.036 & \\
\hline
\end{tabular}


Note: The figures in italics are the standard deviations

The Lorenz curves in figure 6 for the whole population confirm the above results by showing that there is hardly any difference in distribution before and after the simulation.

Figure 6: Lorenz Curves

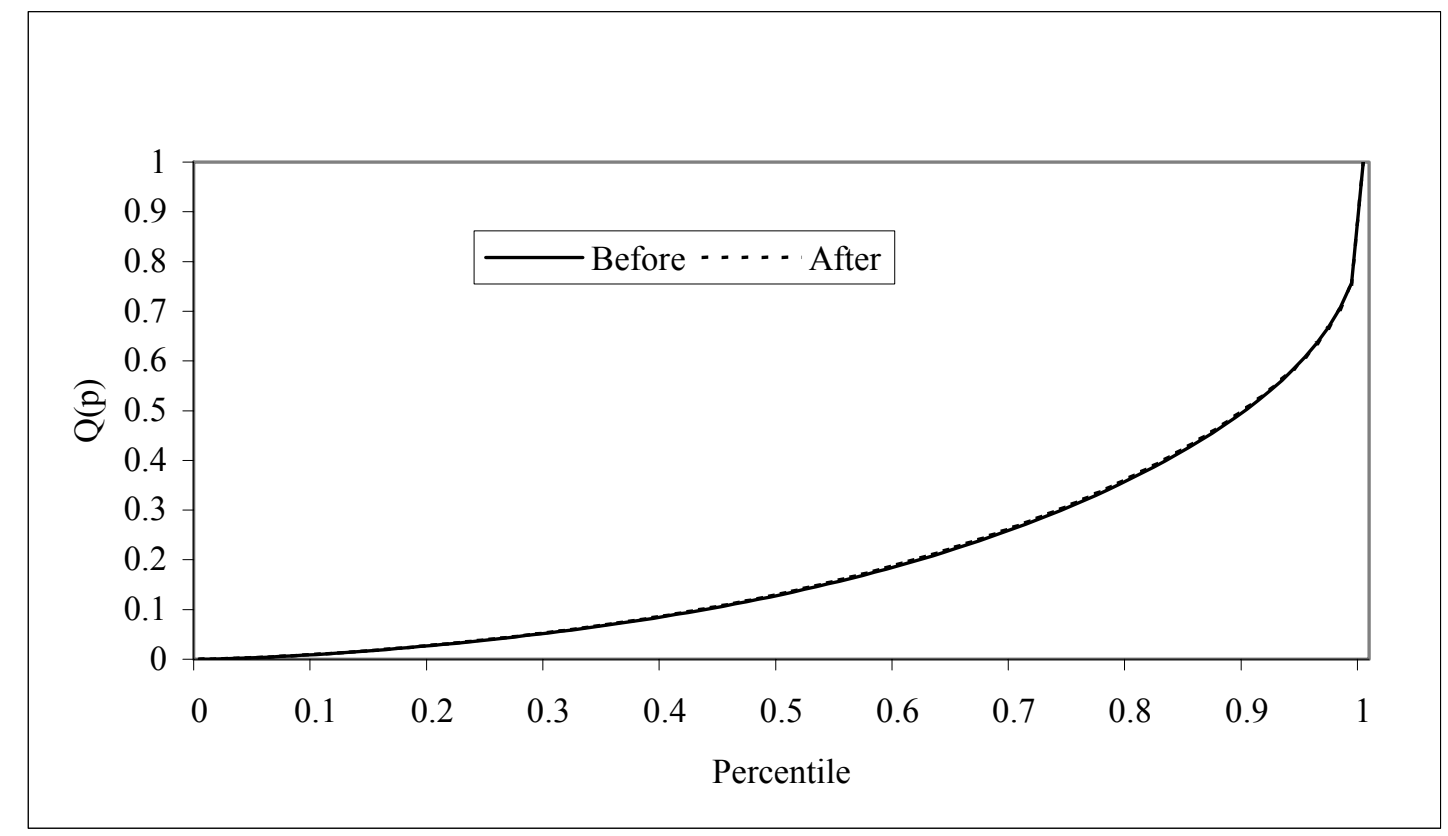

The theoretical argument is that in a country where the export industries are intensive in unskilled labour, liberalization is predicted to reduce poverty in the long run. For instance, Kruger (2000) analysed the impact of trade liberalization in Nicaragua and the results showed that removing trade restrictions reduced prices for agricultural products. This was outweighed by the income effect of the decline in prices of consumption goods. The overall effect indicated that the net real income for the most poor increased by $2.3 \%$, and real incomes for all the poor increased by $1.7 \%$. Zimbabwe, like in the case of the Latin American country, has a strong agricultural export sector and it does not seem 
representative for most African countries or some LDCs in general. Therefore, trade liberalization is expected to realise long run welfare gains. In some cases where agriculture is protected, results may be different. Cockburn (2001) found that for Nepal, a complete removal of tariffs reduced poverty in urban areas but increased it in rural areas especially in the case of those moderately poor. The poverty results are different from ours for the reason that the economies of the two countries are different. In Nepal, liberalisation depressed the price of rice on which many rural households relied. In the case of Zimbabwe on the other hand, liberalisation benefits the agricultural exports and thus the incomes of agriculture workers. These differences in results further merit the importance of empirical studies.

We must point out that the magnitudes of poverty and inequality changes are quite small when compared to the magnitude of the simulation. This is quite common in the literature. CGE models are notorious for small poverty effects that they generate. Similar magnitudes of numbers were also reported by Cockburn (2001) and Cororaton (2003). There is a growing literature, which can be described as 'the hunt for big numbers' which addresses this particular issue (Roland-Holst, 2003). The recent budding work on dynamic CGE analysis of trade policy as well as studies using increasing returns to scale technology are prominent themes in this type of work.

\section{Summary and conclusion}

The paper uses a micro simulation CGE model to study the impact on poverty of trade liberalisation in Zimbabwe. The model is static in nature and of the neoclassical type. It is based on the Exter+ family of models developed by Decaluwé et al. (2001) and Cockburn et al. (2003). It contains sixteen sectors, four factors of production and fourteen thousand 
and six households. The data are from 1995. The complete removal of tariffs favours export oriented sectors. The unskilled labour factor used intensively in agriculture, mining and services benefits from this policy. Most manufacturing sectors shrink leading to a fall in demand for skilled labour and capital. These factors see a reduction in their remuneration for equilibrium to occur. Returns to land increase as export agriculture expands. Overall consumer prices fall and consumption expenditure also falls in the economy.

The policy reduces overall poverty in the economy. On closer inspection we notice that poverty falls more in the urban than in the rural areas. In terms of income distribution, we see that there is hardly any change in inequality but a slight tendency towards more equitable distribution. This is not too surprising given that, in general, poor people gain while the capital owners and the skilled labourers are adversely affected. Although the magnitude of the impacts are relatively small, we are still able to gain valuable insights into the direction of change in poverty due to tariff removal in Zimbabwe.

The methodology used has helped us to understand the impact of this policy on overall poverty as well as on regional poverty. Thus, whereas the macro CGE model might have been able to tell us the changes in income, the richer poverty and inequality information can only be obtained from such a micro-simulation CGE model. The particular changes in poverty and inequality that occur in rural versus urban areas are important for the government in its implementation of such recovery programmes as the social dimensions of adjustment that were implemented in the nineties to try and alleviate the effects of reforms. 


\section{References}

Adelman I. and Robinson, S. (1979) Income distribution policy: A computable general equilibrium model of South Korea, in: Adelman I (1979) The Selected Essays of Irma Adelman. Vol 1. Dynamics and Income Distribution. Economists of the Twentieth Century Series Aldershot, UK, pp. 256-89.

Armington, P. (1969) A theory of demand for products distinguished by place of production. IMF Staff Papers. 16, pp.159-178.

Bautista, R., Lofgren, H. and Thomas, M. (1998) Does trade liberalization enhance income growth and equity in Zimbabwe? The role of complementary policies. TMD Discussion paper No 32 Washington DC: IFPRI.

Bhalla, A., Chitiga-Mabugu, M., Davies, R. and Mabugu, R. (2000) Globalisation and sustainable human development for Zimbabwe. Occasional paper, UNCTAD/UNDP/, Geneva, October.

Central Statistical Office (CSO). (1999) Income, consumption and expenditure survey report 1995/1996. (November), Harare, Zimbabwe.

Central Statistical Office (CSO). (2000) National accounts 1985-1998 (January), Harare, Zimbabwe.

Chitiga-Mabugu, M. (2001) Income distribution effects of trade liberalization: A CGE analysis, in: Mumbengegwi, C. (ed), Macroeconomic and Structural Adjustment Policies in Zimbabwe, (Palgrave: Houndsmill), pp. 221-233.

Cockburn, J., Decaluwé, B. and Robichaud, V. (2004) Trade liberalization and poverty: A CGE analysis of the 1990s experience. Poverty and economic policy network (PEP), TM, Available at: http://www.PEP-NET.ORG/

Cockburn, J. and Cloutier, M.-H. (2002) How to build an integrated CGE microsimulation model: Step-by step instructions with an illustrative exercise. equilibrium micro simulation analysis. Poverty and economic policy network (PEP) working paper Available at: http://www.PEP-NET.ORG/

Cockburn, J. (2001) Trade liberalization and poverty in Nepal: A computable general equilibrium micro simulation analysis. CREFA working paper (01-18). Available at: http://www.crefa.ecn.ulaval.ca/cahier/0118.pdf

Cogneau, D. Robilliard, A. S. (2000) Growth, distribution and poverty in Madagascar: Learning from a microsimulation model in a general equilibrium framework. Trade and Macroeconomic Division, International Food Policy Research (IFPRI), TMD Discussion papers no 61, February.

http://www.ifpri.cgiar.org/divs/tmd/dp/papers/tmdp61.pdf 
Cororaton, C, B. (2003) Analysis of trade reforms, income inequality and poverty using microsimulation approach: The case of the Philippines. Philippines Institute of Development Studies ( PIDS) Discussion Paper Series ,. pp. 2003-09.

Davies, J.B. (2003) Microsimulation, CGE and macro modelling for transition and developing economies, mimeo, University of Western Ontario.

Davies, R. and Rattsø, J. (1994) Zimbabwe: From Liberation to Liberalisation, in L. Taylor (ed.), The Rocky Road to Reform: Adjustment, Income Distribution and Growth in the Developing World, (Cambridge: MIT Press), pp.321-342.

Davies, R., Rattsø, J. and Torvik, R. (1994). The macroeconomics of Zimbabwe in the 1980's: A CGE-model analysis. Journal of African Economies 3, pp.153-198.

Davies, R., Rattsø, J. and Torvik, R. (1998). Short-run consequences of trade liberalization in Zimbabwe: A CGE-model analysis. Journal of Policy Modeling 20, pp. 305-333.

Decaluwé, B., Dumont, J-C. and Savard, L. (1999) Measuring Poverty and Inequality in a Computable General Equilibrium Model. Working Paper 99-20 CREFA, Laval University, Quebec.

Demery, D. and Demery, L. (1991) Adjustment and Equity in Malaysia. OECD, Development Centre. Paris.

Duclos J., Araar, A. and Fortin, C. (2002) DAD4.3: Distributive Analysis. Laval University, Quebec.

Foster J., Greer, J. and Thorbecke, E. (1984) A Class of Decomposable Poverty Measures. Econometrica, 52(3), pp.761-766.

Government of Zimbabwe. (1996) 1995 Poverty Assessment Study Survey (PASS). Main Report, (MPSLSW), Harare, Zimbabwe.

Government of Zimbabwe. (1991) Zimbabwe: A Framework for Economic Reform 1991-95. Government Printers, Harare, Zimbabwe.

Elbadawi, I.A. and Schmidt-Hebbel, K. (1991) Macroeconomic structure and policy in Zimbabwe, Working Paper 771, Country Economics Department, The World Bank.

Kanyenze, G. (1995) Human Resource development in Zimbabwe: beyond the economic structural adjustment programme, Zimbabwe Congress of Trade Unions, Harare.

Kruger, D. (2000) "Redistribution effects of agricultural incentives policies in Nicaragua," background paper for the Nicaragua Poverty Assessment 2000 (College Park: University of Maryland).

Mabugu, R. (2001) Short run effects of tariff reform in Zimbabwe: applied general equilibrium analysis. Journal of African Economies, 10(2), pp. 174-190. 
Orcutt, G. (1957) A new type of socio-economic system. Review of Economics and Statistics, 58, pp. 773-797.

Pakkiri, L. and Moyo. N.P. (1986) Foreign exchange policies: the case of Zimbabwe. IDRC Workshop on Economic Structure and Macroeconomic Management, Harare.

Piggott, J. and Whalley, J. (1985) UK Tax Policy and Applied General Equilibrium Analysis. Cambridge, Cambridge University Press.

Rajan R. S. and Bird, G. (2002) Trade liberalization and poverty: where do we stand?, Centre for International Economic Studies, University of Adelaide, Australia.

Rattsø, J. and Torvik, R. (1998) Zimbabwean trade liberalisation: ex post evaluation. Cambridge Journal of Economics, 22, pp.325-346.

Ravallion, M. (1994) Poverty Comparisons. Harwood Academic Publisher.

Reimer J. J. (2002) Estimating the poverty impacts of trade liberalization. Draft, Perdue University.

Reserve Bank of Zimbabwe. (1997) Annual Report and Statements of Accounts for the Year 1997. Harare, Zimbabwe.

Roland-Holst, D. (2003) Model specification, data and structural parameters: a narrative summary of conference contributions, Économie internationale, 94-95, pp. 315-332.

Savard, L. (2004) Poverty and inequality analysis within a CGE framework: a comparative analysis of the representative agent and micro-simulation approaches, IDRC, Canada.

Stifel, D. and Thorbecke, E. (2003) A dual-dual model of an archetype African economy: trade reform, migration and poverty. Journal of Policy Modeling, 25, pp. 207-235.

Winters, A.L. (2000) Trade, trade policy and poverty: What are the links? Centre For Economic Policy Research Paper No. 2382.

Winters, A.L., McCulloch, N. and McKay, A. (2002) Trade liberalization and poverty: the empirical evidence. Center for Research in Economic Development and International Trade, (University of Nottingham).

World Bank. (2002) Zimbabwe at a Glance: Available at http://www.worldbank.org/data/countrydata.

World Bank. (2004) Zimbabwe Country Assistance Evaluation. Report number 29058, Washington DC. 


\section{Appendix A : Miscellaneous Data}

Table A1: Various initial sectoral shares

\begin{tabular}{|c|c|c|c|c|c|}
\hline Sectors & $\begin{array}{r}\text { Sectoral } \\
\text { value addedl } \\
\text { total value } \\
\text { added } \\
\end{array}$ & $\begin{array}{r}\text { Sectoral } \\
\text { imports/ total } \\
\text { imports }\end{array}$ & $\begin{array}{r}\text { Sectoral } \\
\text { exports/ } \\
\text { total exports }\end{array}$ & $\begin{array}{r}\text { sectoral } \\
\text { imports/ } \\
\text { sectoral output } \\
\end{array}$ & $\begin{array}{r}\text { Sectoral } \\
\text { exports/ } \\
\text { sectoral } \\
\text { production }\end{array}$ \\
\hline Agrain & 2.4 & 0.4 & 2.2 & 6.7 & 25.9 \\
\hline Ahorticu & 0.6 & 0.1 & 0.2 & 2.7 & 7 \\
\hline Ateacoffe & 0.5 & 0 & 1.8 & 0 & 78.2 \\
\hline Acottobc & 7.3 & 0.2 & 27.9 & 6 & 90.9 \\
\hline Aothcrop & 1.7 & 0 & 3.9 & 0 & 49.4 \\
\hline Alivestock & 2.6 & 0 & 6 & 0 & 48.9 \\
\hline Afishery & 0.1 & 0 & 0 & 0 & 0 \\
\hline Aforestry & 0.3 & 0 & 0 & 0 & 0 \\
\hline Amining & 4.5 & 1.3 & 12.5 & 9 & 50.3 \\
\hline Afodproc & 7.8 & 6.7 & 2.5 & 17.1 & 7.4 \\
\hline Atextile & 2.1 & 3.5 & 1.7 & 20.5 & 12.9 \\
\hline Allothmauf & 17.2 & 82.3 & 18.7 & 53.3 & 22.2 \\
\hline Aconstrn & 3.1 & 0 & 0 & 0 & 0 \\
\hline Aewtdts & 19.4 & 0 & 0 & 0 & 0 \\
\hline Apubsv & 14 & 0 & 0 & 0 & 0 \\
\hline Aprivsv & 16.5 & 5.6 & 22.5 & 10.6 & 31.6 \\
\hline ALL* & 100 & 100 & 100 & 34.6 & 34.2 \\
\hline
\end{tabular}

${ }^{*}$ Average variation for volumes - Laspeyres index variation for prices 